\title{
Effectiveness of Market Results Diversified Palm Products and Constraints of Capital, Financing and Marketing
}

\author{
Marlon Sihombing \\ Universitas Sumatera Utara \\ Medan, Indonesia \\ marlon@usu.ac.id \\ Iskandar Muda \\ Universitas Sumatera Utara \\ Medan, Indonesia \\ iskandar1@usu.ac.id
}

\author{
Erni Jumilawati \\ Universitas Sumatera Utara \\ Medan, Indonesia \\ erni@usu.ac.id \\ Abikusno Dharsuky \\ Universitas Sumatera Utara \\ Medan, Indonesia \\ abikusno@usu.ac.id
}

\begin{abstract}
The purpose of this research is to know the effectiveness and constraints of Capital, Financing and Marketing of Diversification of Palm Products resulting from the development of Regional Innovation System. The type of this research is explanatory survey and analyzed with quantitative descriptive. Respondents are business perpetrators of palm products derived 167 respondents. This research is conducted by conducting primary data survey from upstream and downstream of diversified Crude Palm Oil (CPO). The results show the weakness of marketing network system and capital to the utilization of diversification of derivative products in the scope of Regional Innovation System.
\end{abstract}

Keywords-Capital; Financing; Network Marketing and diversification of palm oil derivative products.

\section{INTRODUCTION}

Oil palm plantations managed by the people have limited land area, will produce a limited number of fresh fruit bunches so sales are difficult to sell if they want to sell them directly to the industry [1]. Therefore, farmers must sell village level traders close to the location of the garden or through the Cooperative, then to the wholesalers to the processing industry. The length of the marketing chain on smallholder estates causes the level of profit earned by farmers is relatively small. The marketing of fresh fruit palm fruit bunches has become one of the constraints of the self-help smallholders to date. Growing TBS direct sellers' access to palm oil companies or factories is still difficult so that dependence on middlemen is very high. Direct sales can be done if it has cooperated with various terms or partner with the Plasma. The rules of the company become one of the obstacles, as well as the weak bargaining position of smallholders as a capital for cooperation. Therefore, efforts are needed to increase farmers' income by fostering and shortening marketing distribution. The government regulates the function of each actor in the marketing chain with accompanying profitable marketing margin arrangements for each of the actors in the marketing chain with accompanying marketing margin arrangements along with profitable marketing margin arrangements for each of the actors.

\section{METHOD}

This study uses primary data. The hypothesis was tested by using Structural Equation Modeling (SEM) with SMART PLS software. The data analysis technique in this research employed Structural Equation Modeling (SEM). SEM is a set of statistical techniques allowing testing of a series of relationships simultaneously. Furthermore, in the data processing, the writer used the aid from software SMART-PLS Structural Equation Modeling, which was one of the multivariate analyses capable of analyzing the variable relationships in complex manner [8], [12], [13], [14], [24], \& [25].

The hypotheses were tested using Structural Equation Modeling (SEM) with Smart-PLS software tools. The equation is formed as follows:

$$
\begin{aligned}
& \mathrm{Y}=\alpha+\mathrm{b} 1 \mathrm{X} 1+\mathrm{b} 2 \mathrm{X} 2++\mathrm{b} 3 \mathrm{X} 3+\mathrm{e} \\
& \mathrm{X} 1=\text { Capital } \\
& \mathrm{X} 2=\text { Financing } \\
& \text { X3 = Marketing } \\
& \mathrm{Y}=\text { Development of Regional Innovation } \\
& \text { System } \\
& \mathrm{b} 1, \ldots \mathrm{b} 3=\text { Coefficient } \\
& \alpha \quad=\text { Constant } \\
& \mathrm{e} \quad=\text { Error }
\end{aligned}
$$


This phase is done to test the suitability of the model to evaluate the goodness-of-fit index [30], [31], [30], [35] \& [42]. Analysis using SEM requires some suitability index to measure the correctness of data and models to be filed.

\section{RESULT AND DISCUSSION}

\section{A. Result}

Inner model evaluation through the bootstrapping menu also generates T-statistics values that will be used to test the hypothesis. The criteria are T-statistic> 1.66 [3], [18], [26], [34] \&[36]. The result of T-statistics value in the table path coefficients is presented in the following figure:

Figure 1. T-statistics value

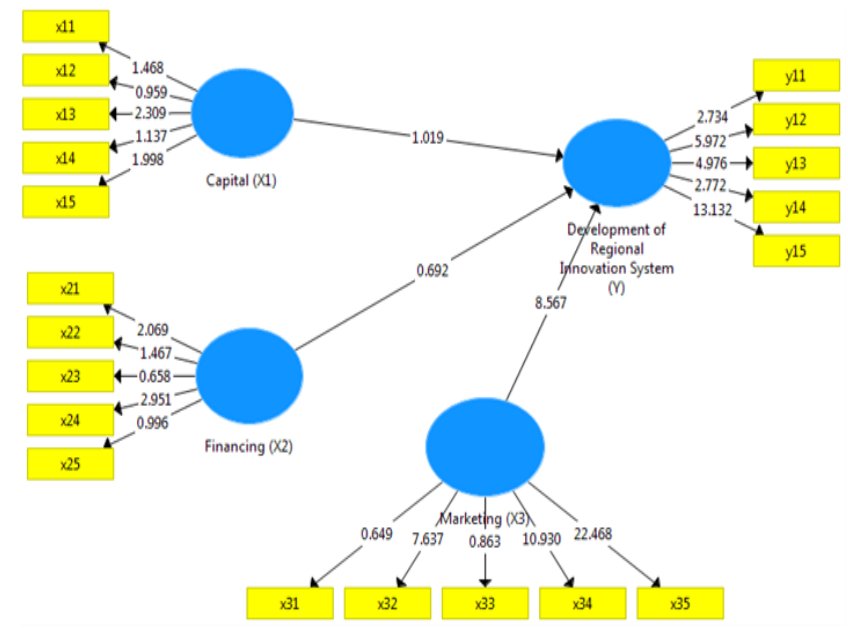

Table 1. The result of bootstrapping

\begin{tabular}{|l|c|c|c|c|c|}
\hline & $\begin{array}{c}\text { Original } \\
\text { Sample (0) }\end{array}$ & $\begin{array}{c}\text { Sample } \\
\text { Mean } \\
(\mathrm{M})\end{array}$ & $\begin{array}{c}\text { Standard } \\
\text { Deviation } \\
\text { (STDEV) }\end{array}$ & $\begin{array}{c}\mathrm{T} \\
\text { Statistics }\end{array}$ & P Values \\
\hline $\begin{array}{l}\text { Capital (X1) > Development of } \\
\text { Regional Innovation System (Y) }\end{array}$ & 0,112 & 0,104 & 0,110 & 1,019 & 0,309 \\
\hline $\begin{array}{l}\text { Financing (X2) > Development } \\
\text { of Regional Innovation System } \\
\text { (Y) }\end{array}$ & 0,076 & 0,121 & 0,110 & 0,692 & 0,489 \\
\hline $\begin{array}{l}\text { Marketing (X3) > Development } \\
\text { of Regional Innovation System } \\
(\mathrm{Y})\end{array}$ & 0,593 & 0,585 & 0,069 & 8,567 & 0,000 \\
\hline
\end{tabular}

Based on the test results show that a good marketing system will increase the Development of Regional Innovation System. Capital and Financing variables have no significant effect.
Figure 2. Capital (X1)

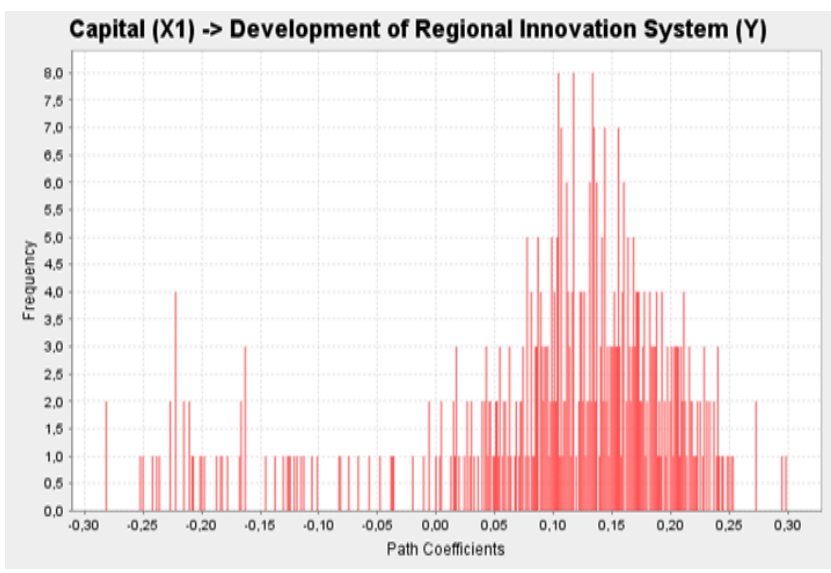

Figure 3. Fiancing (X2)

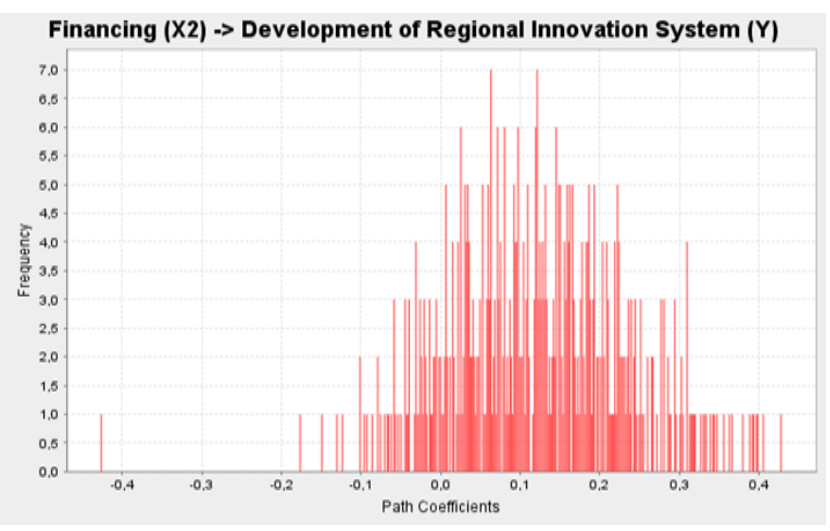

Figure 4. Marketing (X3)

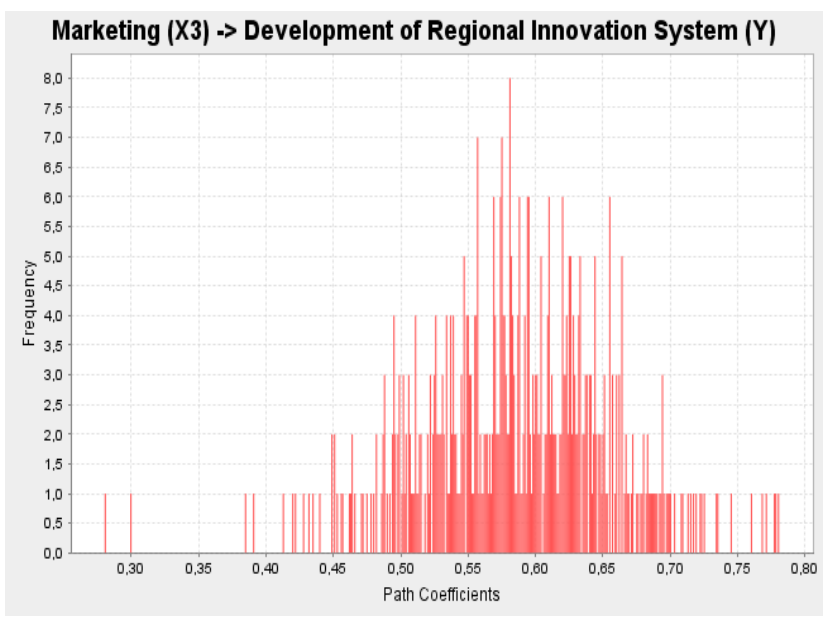

Based on the above table the indirect effect produces coefficient of 0.005 , smaller than $1.66(\alpha=5 \%)$ then the decision of hypothesis testing reject $\mathrm{HO}$ and accept the hypothesis Ha [37],.In addition to hypothesis testing through the bootstrapping menu that produces T-statistics, inner model evaluation is also done by reviewing the R-Square value [27], 
[28]\& [29]. The R-square value generated from the inner model evaluation is presented in the following table:

Table 2. R-Square Value

\begin{tabular}{|l|r|r|}
\hline & R Square & $\begin{array}{c}\text { R } \\
\text { Square } \\
\text { Adjusted }\end{array}$ \\
\hline Development of Regional Innovation System (Y) & 0,440 & 0,430 \\
\hline
\end{tabular}

Figure 5. F-Square Value

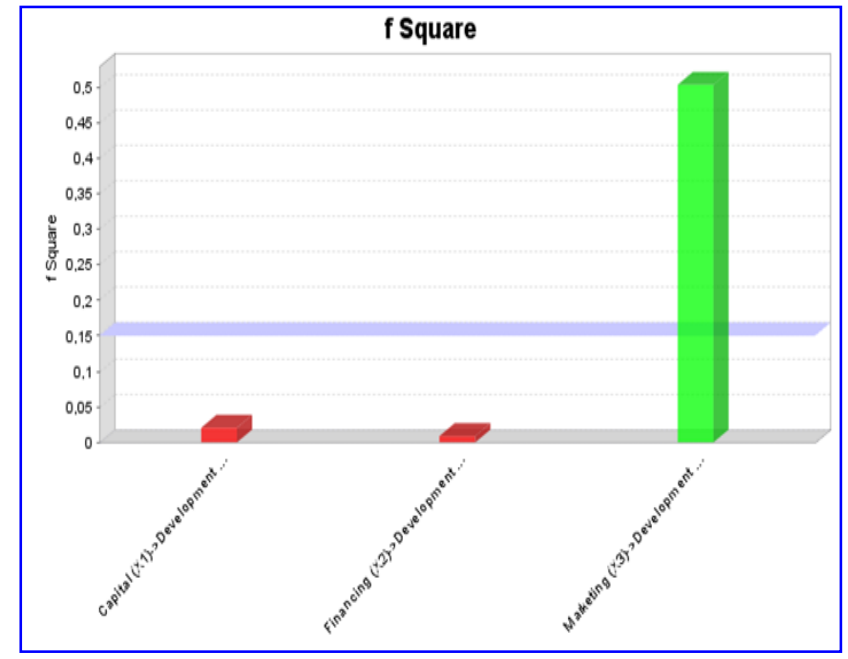

\section{B. Discussion}

Facilitated by the Government to cooperate with plantation business actors, marketing associations, commodity associations, commodity councils, other institutions and/or the community. The cooperation is carried out by organizing market information, promotion, and developing the marketing center of plantation commodities, both inside and outside the country [43]\&[44]. In conducting marketing cooperation with companies, the institutional identity of the smallholders should be clear and documented through documents procedure or certificate from the Plantation Office showing the institutional formation of smallholders, whether in the form of cooperative enterprises with legal entities or groups of smallholders [38], [39],[40]\&[41]. Institutional planters also have documentation of the plantation members accompanied by land area, age of palm plantation, and other information related to the profile and data of the planters. Institutional planters can strengthen the bargaining position of smallholders in marketing cooperation with companies [17]. The institutional planters function to unify the approach of the cultivation system at the level of different self-supporting smallholders and not integrated in sustainable development [23]. Ideally, the cooperation of marketing by the self-supporting smallholders with the companies is done through the institutional self-help smallholders, either in the form of farmers 'groups or planters' cooperatives, which are experienced. Because institutional planters have an important role in doing things such as service functions in plantation cultivation systems, facilitation of access to financial institutions, government, companies to market access.
Organizational growers become the most important indicators in strong institutions, planters can unite and collectively develop alternative systems in smallholder plantations as well as an easy requirement in the sale of selfhelp smallholder farmers. By organizing independent smallholders who have been scattered can consolidate their institutions in a sustainable approach. This approach can be done through capacity building of planters, applying GAP practices well based on sustainability principles [21]\&[22]. Through these institutions, identification of the number of independent smallholders, plantation area of each member of the self-help smallholders, sales partner information, and information about the percentage of production tonnage [15]. One aspect that needs to be analyzed related to market identification is how to face market demand for palm oil industry stakeholders, including one of them self-help smallholders, on market commitment and demands for sustainable palm oil supply [2], [4], [5]\&[33]. This demand is one of the conditions ahead in implementing the sales cooperation TBS smallholders to implemented or committed in the approach of sustainable palm oil.

In addition, efforts to improve the productivity of oil palm growers can be done by granting loans from bank institutions and financing institutions. Credits can be granted on bail or unsecured [6]\&[7]. Unsecured credit is very dangerous to the bank's position, considering that if the customer experiences a traffic jam it will be difficult to cover the losses on the loan disbursed [9], [10]\&[11]. Conversely, with credit guarantees is relatively safer considering any bad credit will be covered by the guarantee. Unsecured credit is a solution where credit is not given by guarantee of certain goods. Usually given to companies that really bonafit and professional, so the possibility of credit is stuck very small. It can also be unsecured credit only with an assessment of its business prospects or with consideration for weak economic entrepreneurs.

\section{CONCLUSIONS}

The results show the weakness of marketing network system and capital to the utilization of diversification of derivative products in the scope of Regional Innovation System.

\section{REFERENCES}

[1] Anderson, P. "Free, prior and informed consent? Indigenous peoples and the palm oil boom in Indonesia". The palm oil controversy in Southeast Asia. A transnational perspective, (2013). pp. 244-258.

[2] Asante, E. A. "The case of Ghana's president's special initiative on oil palm (PSI-oil palm) (No. 2012: 11). (2012). DIIS Working Paper.

[3] Azlina, Nur., Amir Hasan, Desmiyawati\&Muda, I. "The Effectiveness of Village Fund Management (Case Study at Villages in Coastal Areas in Riau)". International Journal of Economic Research. Vol.14 Issue 12. (2017). pp.325-336.

[4] Baumann, P. Equity and efficiency in contract farming schemes: the experience of agricultural tree crops (Vol. 111). (2000). London: Overseas development institute.

[5] Biermann, F., \& Gupta, A. "Accountability and legitimacy in earth system governance: a research framework'. Ecological economics, 70(11), (2011). pp.1856-1864. 
[6] Bitzer, V., \& Glasbergen, P. "Business-NGO partnerships in global value chains: part of the solution or part of the problem of sustainable change?". Current Opinion in Environmental Sustainability, 12, (2015). pp.35-40.

[7] Caroko, W., Komarudin, H., Obidzinski, K., \& Gunarso, P. Policy and institutional frameworks for the development of palm oil-based biodiesel in Indonesia. (2011). CIFOR.

[8] Dalimunthe., D.M.J.,Fadli, and Muda, I. "The application of performance measurement system model using Malcolm Baldrige Model (MBM) to support Civil State Apparatus Law (ASN) number 5 of 2014 in Indonesia". International Journal of Applied Business and Economic Research. Vol.14 Issue 11. (2016). pp.7397-7407.

[9] Dev, S. M., \& Rao, N. "Food processing and contract farming in Andhra Pradesh: A small farmer perspective". Economic and Political weekly. (2005). pp.2705-2713.

[10] Dimelu, M. U., \& Anyaiwe, V. "Priorities in smallholder oil palm producers in Ika local government area of Delta state: Implication for agricultural extension service in Nigeria". World J. Agric. Sci, 7, (2011). pp.117-123.

[11] Efidayanthi, Rischa and Rachmat Sumanjaya. The Role of Banking To Palm Coal Farmers In Sosa District District Padang Lawas, North Sumatera. $2016 . \quad$ Retrieved from https://media.neliti.com/media/publications/14749-ID-peran-perbankanterhadap-petani-kelapa-sawit-di-kecamatan-sosa-kabupaten-padang.pdf . Acceses on 01 August 2017.

[12] Erlina., Ari Saputra \& Muda, I. "Antecedents of Budget Quality Empirical Evidence from Provincial Government In Indonesia". International Journal of Economic Research. Vol. 14 Issue 12. (2017). pp.301-312.

[13] Erlina., Ari Saputra \& Muda, I. "The Analysis of the Influencing Factors of Budget Absorption". International Journal of Economic Research. Vol. 14 Issue 12. (2017). pp.287-300.

[14] Erlina.,"ConflictofInterestImpact: FactorsAnalysisAffectingtheBudgetQualityinMedanCity". International Journal of Economic Research. Vol.14 Issue 12. (2017). pp.135-145.

[15] Grajales, J. "State Involvement, Land Grabbing and Counter-Insurgency in Colombia". Development and Change, 44(2), (2013). pp. 211-232.

[16] Gusnardi., Riadi, R.M., and Muda, I. "Competency mapping and analysis of students competency based on economics subject national examination and its alternative solutions in state high schools at Pekanbaru". International Journal of Economic Research. Vol.3 Issue 5. (2016). pp.2133-2148.

[17] Handoko, Bagus., Sunaryo \&Muda, I. "Difference Analysis of Consumer Perception of Motorcycle Product Quality". International Journal of Economic Research. Vol. 14 Issue 12. (2017). pp.363-379.

[18] Hasan., Amir, Gusnardi \&Muda, I.“Analysis of Taxpayers and Understanding Awareness Increase in Compliance with Taxpayers Individual Taxpayers". International Journal of Economic Research. Vol.14 Issue 12. (2017). pp. 75-90.

[19] Hidayat, N. K., Glasbergen, P., \& Offermans, A. "Sustainability certification and palm oil smallholders' livelihood: a comparison between scheme smallholders and independent smallholders in Indonesia". International Food and Agribusiness Management Review, 18(3). (2015). pp.25-48.

[20] Hospes, O. "Marking the success or end of global multi-stakeholder governance? The rise of national sustainability standards in Indonesia and Brazil for palm oil and soy". Agriculture and human values, 31(3), (2014). pp.425-437.

[21] Hospes, O., \& Kentin, A. "Tensions Between Global-Scale and National-Scale Governance: The Strategic Use of Scale Frames to Promote Sustainable Palm Oil Production in Indonesia”. Scale-sensitive governance of the environment, (2014). pp.203-219.

[22] Julia, \& White, B. "Gendered experiences of dispossession: oil palm expansion in a Dayak Hibun community in West Kalimantan". The Journal of Peasant Studies, 39(3-4), (2012). pp.995-1016.

[23] Lee, J. S. H., Garcia-Ulloa, J., Ghazoul, J., Obidzinski, K., \& Koh, L. P. "Modelling environmental and socio-economic trade-offs associated with land-sparing and land-sharing approaches to oil palm expansion”. Journal of applied ecology, 51(5), (2014). pp.1366-1377.
[24] Lubis., A.,Torong, Z.B., and Muda, I. "The urgency of implementing balanced scorecard system on local government in North Sumatra Indonesia". International Journal of Applied Business and Economic Research. Vol.14 Issue 11. (2016). pp.7575-7590.

[25] Lubis., A.F., Lubis, T.A., and Muda, I. "The role of Enterprise Resource Plan (ERP) configuration to the timeliness of the financial statement presentation". International Journal of Applied Business and Economic Research. Vol.14 Issue 11. (2016). pp.7591-7608.

[26] Lutfi., M.,Nazwar, C., and Muda, I "Effects of investment opportunity set, company size and real activity manipulation of issuers in Indonesia Stock Exchange on stock price in Indonesia". International Journal of Economic Research. Vol.13 Issue 5. (2016). pp.2149-2161.

[27] Macadam, R. D. "From pushing production inputs to empowering the community: a case study in the transformation of an extension agency". Australian Journal of Experimental Agriculture, 40(4), (2000). pp.585-594.

[28] McCarthy, J. F. "Processes of inclusion and adverse incorporation: oil palm and agrarian change in Sumatra, Indonesia". The Journal of peasant studies, 37(4), (2010). pp.821-850.

[29] McGregor, A., Bourke, M., Manley, M., Tubuna, S., \& Deo, R. Pacific island food security: situation, challenges and opportunities. (2009).

[30] Muda., I and Abykusno Dharsuky. "Impact of Region Financial Information System (SIKD) Quality, Role Ambiguity And Training on Precision of Financial Statement of Local Government Presentation In North Sumatra". International Journal of Applied Business and Economic Research, Vol.13 Issue 6. (2015). pp.4283-4304.

[31] Muda., I, Deni Yuwilia Wardani, Erlina, Azhar Maksum, Ade Fatma Lubis and Rina Bukit. "The Influence of Human Resources Competency and The Use of Information Technology on The Quality of Local Government Financial Report with Regional Accounting System as an Intervening". Journal of Theoretical and Applied Information Technology. Vol.95 Issue 17. (2017). pp.1432-1451.

[32] Muda., I, Dharsuky. A., Siregar, H.S., and Sadalia, I. "combined loading and Cross-dimensional loadings timeliness of presentation of financial statements of local government". IOP Conference Series : Materials Science and Engineering. Bandung, (2017). 180. doi: 10.1088/1757899X/180/1/012099.

[33] Muda., I, Marlon Sihombing, Erni Jumilawati and Abikusno Dharsuky. "Critical Success Factors Downstream Palm Oil Based Small And Medium Enterprises (SME) In Indonesia”. International Journal of Economic Research. Vol.13 Issue 8. (2016). pp. 3531-3538.

[34] Muda., I., Rafiki, A., \& Harahap, M. R. "Factors Influencing Employees' Performance: A Study on the Islamic Banks in Indonesia". International Journal of Business and Social Science, Vol.5Issue 2. (2014). pp. 73-80.

[35] Muda., I.,Dharsuky, A.,Sadalia, I., and Siregar, H.S. "Impact of capital investments and cash dividend policy on Regional Development Bank (BPD) PT. Bank Sumut to the district own source revenue and economic growth". International Journal of Applied Business and Economic Research. Vol.14 Issue 11. (2016). pp.7863-7880.

[36] Muda., Iskandar. "The Effect of Supervisory Board Cross-Membership and Supervisory Board Members' Expertise to The Disclosure of Supervisory Board's Report : Empirical Evidence From Indonesia". European Research Studies Journal. Vol.XX Issue 3A. (2017). pp.702716.

[37] Nasir, Azwir., Yesi Mutia Basri, Kamaliah \&Muda, I. "Effectiveness of Potential Tax Region as the Real Local Revenue Sources in Riau Coastal Area". International Journal of Economic Research. Vol.14 Issue 12. (2017). pp.313-324.

[38] Neilson, J. "Global markets, farmers and the state: sustaining profits in the Indonesian cocoa sector". Bulletin of Indonesian Economic Studies, 43(2), (2007). pp.227-250.

[39] Nikoloyuk, J., Burns, T. R., \& de Man, R. "The promise and limitations of partnered governance: The case of sustainable palm oil". Corporate Governance: The international journal of business in society, 10(1), (2010). pp.59-72.

[40] Pesqueira, L., \&Glasbergen, P.” Playing the politics of scale: Oxfam's intervention in the Roundtable on Sustainable Palm Oil". Geoforum, 45, (2013). pp.296-304. 
[41] Potter, L. "Oil palm and resistance in West Kalimantan, Indonesia". Agrarian angst and rural resistance in contemporary Southeast Asia, 4(2009). 105.

[42] Sadalia, .Isfenti., Nur Ahmadi Bi Rahamani \&Muda, I. "The Significance of Internet Based Financial Information Disclosure on Corporates' Shares in Indonesia". International Journal of Economic Research. Vol.14 Issue 12. (2017). pp.337-346.

[43] Schouten, G., \& Glasbergen, P. 'Private multi-stakeholder governance in the agricultural market place: an analysis of legitimization processes of the roundtables on sustainable palm oil and responsible soy". International Food and Agribusiness Management Review, 15(B), (2012). pp.53-78.

[44] Soyebo, K. O., Farinde, A. J., \& Adetayo, E. D. "Constraints of oil palm production in Ife central local government area of Osun State, Nigeria". Journal of Social Sciences, 10(1), (2005). pp.55-59.

[45] Yahya., Idhar., Torong, Z.B., and Muda, I.. "Influence Behavior in Legislature Budget Development of Regions in the Province of Aceh and North Sumatra". International Journal of Economic Research, Vol.14 Issue 8. (2017). pp. 147-159. 